\author{
Ана БАТАС \\ Универзитет у Београду \\ Филолошки факултет
}

\title{
МЕСТО АКЦЕНТА У НАСТАВИ СРПСКОГ ЈЕЗИКА КАО СТРАНОГ
}

Наслов овог прилога може упућивати на значај који акценат српског језика има у настави српског језика као страног, али и на одређивање наглашених слогова. Иако би се било занимљиво бавити првом од две интерпретације наслова, у овом прилогу бавимо се само потоњом. Одређивање наглашених слогова, њихово изговарање, препознавање различитих облика речи захваљујући промени места акцента, несумњиво представља изазов приликом учења језика са покретним нагласком.

Као што је познато, језике према покретљивости нагласка делимо на оне са сталним и на оне са покретним нагласком (Гард 1993: 10, Пецо 1991: 19). Српски језик у том погледу спада у мешовит тип, с обзиром на то да су силазни акценти у највећем броју случајева везани за први слог, а да се узлазни налазе на сваком слогу осим последњег (Јокановић-Михајлов 2012: 14). У језицима са покретним нагласком наглашавање различитих слогова често је контрастивно, а у српском језику контрастиван може бити и квантитет наглашених и ненаглашених слова, као и квалитет наглашених (в. следећу табелу са примерима).

\begin{tabular}{|l|l|l|}
\hline \multicolumn{1}{|c|}{$\begin{array}{c}\text { Место } \\
\text { акцента }\end{array}$} & \multicolumn{1}{c|}{$\begin{array}{c}\text { избори } \\
\text { (ном. множине } \\
\text { им. „избор”) }\end{array}$} & \multicolumn{1}{c|}{$\begin{array}{c}\text { избори (2. л. једнине } \\
\text { императива } \\
\text { гл. „изборити”) }\end{array}$} \\
\hline $\begin{array}{l}\text { Квантитет } \\
\text { наглашеног } \\
\text { слога }\end{array}$ & $\begin{array}{l}\text { рада (пр. „рад” у ном. } \\
\text { једнине ж. рода) }\end{array}$ & $\begin{array}{l}\text { рада } \\
\text { (ген. једнине им. „рад”) }\end{array}$ \\
\hline
\end{tabular}




\begin{tabular}{|l|l|l|}
\hline $\begin{array}{l}\text { Квантитет } \\
\text { ненаглашених } \\
\text { слогова }\end{array}$ & $\begin{array}{l}\text { куће } \\
\text { (ген. једнине им. „кућа”) }\end{array}$ & $\begin{array}{l}\text { куће } \\
\text { (ном. множине им. „кућа”) }\end{array}$ \\
\hline $\begin{array}{l}\text { Квалитет } \\
\begin{array}{l}\text { наглашеног } \\
\text { слога }\end{array}\end{array}$ & $\begin{array}{l}\text { замка } \\
\text { (ном. једнине им. „замка”) }\end{array}$ & $\begin{array}{l}\text { замка } \\
\text { (ген. једнине им. „замак”) }\end{array}$ \\
\hline
\end{tabular}

Додатан проблем представљају промене акцената у оквиру морфолошких парадигми и приликом творбе речи, тзв. акцеенатске алтернације (Николић 1961-1962). Сматрамо да је у настави српског језика као страног неопходно акцентима приступити системски, уочавајући акценатске парадигме (Дешић 1976). Ова идеја није никаква новина када се у обзир узме настава других језика. У руском језику, на пример, постоје приручници намењени савладавању акцента руског као страног базирани на овом принципу (Шутова 2013).

За овај прилог изабрали смо да представимо само случајеве када се у парадигмама речи јављају акценатске алтернације по месту акцента, занемарујући остале акценатске алтернације (по квантитету и по квалитету). Сматрамо да је место акцента базични феномен и да би према томе у настави српског језика као страног требало кренути од њега. Други акценатски елементи нису неважни, али на основу искуства у настави акцената можемо тврдити да их без овладавања местом акцента нема сврхе увежбавати.

У даљем тексту изложићемо примере разврстане по врстама речи са коментарима, почевши од именица, преко придева, до глагола. Сваки кружић означаваће један слог, а пуни кружић акцентовани (наглашени) слог.

\section{1. Именице}

Именице мушког рода разврстали смо на три групе: на оне са непроменљивим нагласком и различитим бројем слогова, на оне са непроменљивим нагласком и истим бројем слогова и на оне са променљивим нагласком.

\section{1. Именице мушког рода са непроменљивим местом акиента и различитим бројем слогова}

\begin{tabular}{|c|c|c|c|}
\hline прозор & o & прозора & Oоo \\
\hline ваздух & o & ваздуха & Oоo \\
\hline мајстор & o & мајстора & Oоo \\
\hline разговор & Ooo & разговора & Oooo \\
\hline
\end{tabular}




\begin{tabular}{|l|l|l|l|}
\hline господин & Ооо & господина & Оооо \\
\hline грађанин & Ооо & грађанина & Оооо \\
\hline руководилац* & оо оо & руководиоца & оо оооо \\
\hline
\end{tabular}

*Именица руководилаи (руководиоияа) има различит број слогова упркос непостојаном $a$, јер се поред те алтернације јавља и прелаз $л$ у $о$.

\section{2. Именице мушког рода са непроменьивим местом акиента и истим бројем слогова}

\begin{tabular}{|l|l|l|l|}
\hline ветар & О & ветра & ○ \\
\hline купац & о & купца & о \\
\hline податак & оо & податка & о о \\
\hline недостатак & ооо & недостатка & оо о \\
\hline ватрогасац & ооо & ватрогасца & оо о \\
\hline земљописац & ооо & земљописца & оо о \\
\hline
\end{tabular}

Све именице мушког рода из горње табеле имају исти број слогова у номинативу и осталим падежима, не рачунајући генитив множине и множинска проширења (ветар - ветрови). На самом почетку учења места акцента можда би имало смисла раздвојити именице на ове друге групе да би они који уче српски језик као страни овладали наглашавањем онда када број слогова у речи остаје исти као број слогова у номинативу и онда када се број слогова повећава у зависним падежима' ${ }^{1}$

\section{3. Именице мушког рода са променљивим нагласком}

\begin{tabular}{|l|l|l|l|}
\hline дечак & О & дечака & о о \\
\hline капут & о & капута & о о \\
\hline шешир & о & шешира & о о \\
\hline тротоар & оо & тротоара & оо о \\
\hline крокодил & оо & крокодила & оо о \\
\hline
\end{tabular}

\footnotetext{
${ }^{1}$ Овим примерима нисмо придружили случајеве када у зависним падежима долази до дуљења (продужавања) слога када се сонант налази у рубу (коди), као што је у случајевима палац - палц̧а.
} 


\begin{tabular}{|l|l|l|l|}
\hline тротинет & оО & тротинета & оо о \\
\hline материјал & ооо & материјала & ооо о \\
\hline аутомобил & оооо & аутомобила & оооо о \\
\hline
\end{tabular}

\section{2. Придеви (неодређени вид)}

Придеве смо такође разврстали у три групе: на оне који имају непроменљиви нагласак, а задржавају исти број слогова, на оне који имају непроменљиви нагласак, али им се број слогова повећава и на оне са променљивим нагласком. У обзир смо узимали само неодређени придевски вид пошто се у оквиру парадигме одређеног придевског вида не мења место наглашавања.

\section{1. Придеви са непроменљивим нагласком и истим бројем слогова}

\begin{tabular}{|l|l|l|l|}
\hline танак & Оо & танка & оо \\
\hline модар & о & модра & оо \\
\hline гладак & о & глатка & о \\
\hline пријатан & оо & пријатна & ооо \\
\hline непријатан & Ооо & непријатна & ооо \\
\hline саосећајан & оооо & саосећајна & Оооо \\
\hline
\end{tabular}

2.2. Придеви са непроменљивим нагласком и различитим бројем слогова

\begin{tabular}{|l|l|l|l|}
\hline мекан & Оо & мекана & оо \\
\hline прозван & Оо & прозвана & Оо \\
\hline уходан & оо & уходана & ооо \\
\hline повезан & оо & повезана & ооо \\
\hline убрзан & оо & убрзана & ооо \\
\hline уплакан & оо & уплакана & ооо \\
\hline
\end{tabular}




\section{3. Придеви са променљивим нагласком}

\begin{tabular}{|l|l|l|l|}
\hline широк & о & широка & оОо \\
\hline зелен & о & зелена & оОо \\
\hline црвен & о & црвена & оОо \\
\hline висок & о & висока & оОо \\
\hline шарен & о & шарена & оОо \\
\hline мален & о & малена & оОо \\
\hline
\end{tabular}

\section{3. Глаголи}

У раду о акценатским парадигмама глагола (Батас 2020) издвојили смо следеће глаголске категорије: инфинитив, радни гл. придев, 1. лице једнине презента, 3. лице множине презента и 2. лице једнине императива. У обзир би се могли узети још и акценти аориста и трпног глаголског придева, али се њима тада нисмо бавили. За овај прилог преуредили смо тадашњу класификацију акценатских парадигми глагола уводећи као једини критеријум место акцента.

\section{1. Глаголи са непроменљивим нагласком}

\begin{tabular}{|c|c|c|c|c|}
\hline јести & jeo & једем & једу & једи \\
\hline o & o & Oо & Oо & oo \\
\hline појести & појео & поједем & поједу & поједи \\
\hline ооo & oo & oo & oo & oo \\
\hline желети & желео & желим & желе & жели \\
\hline Oоo & Ooo & ○ & ○。 & ○ \\
\hline пожелети & пожелео & пожелим & пожеле & пожели \\
\hline o & о оо & o & o & o \\
\hline
\end{tabular}




\section{2. Глаголи код којих се нагласак мења у императиву}

\begin{tabular}{|l|l|l|l|l|}
\hline послати & послао & пошаљем & пошаљу & пошаљи \\
\hline Ооо & ооо & ○оо & ○оо & о о \\
\hline
\end{tabular}

3.3. Глаголи код којих се мења нагласак у радном глаголском придеву

\begin{tabular}{|l|l|l|l|l|}
\hline прочитати & прочитао & прочитам & прочитају & прочитај \\
\hline о ооо & оооо & о о & о ооо & о о \\
\hline
\end{tabular}

\section{4. Глаголи код којих се мења нагласак у презенту (у свим облицима)}

\begin{tabular}{|l|l|l|l|l|}
\hline уписати & уписао & упишем & упишу & упиши \\
\hline о оо & ооо & Ооо & Ооо & о о \\
\hline замолити & замолио & замолим & замоле & замоли \\
\hline о оо & ооо & Ооо & Ооо & о о \\
\hline
\end{tabular}

3.4. Глаголи код којих се мења нагласак у императиву и у свим лицима презента осим 3. лица множине

\begin{tabular}{|l|l|l|l|l|}
\hline преспавати & преспавао & преспавам & преспавају & преспавај \\
\hline о оо & ооо & ○оо & ооо & ооо \\
\hline
\end{tabular}

3.5. Глаголи код којих се мења нагласак у императиву и у свим лищима презента

\begin{tabular}{|l|l|l|l|l|}
\hline сарађивати & сарађивао & сарађујем & сарађују & сарађуј \\
\hline оо оо & оо оо & о ооо & о $о$ оо & о ○о \\
\hline
\end{tabular}

3.6. Глаголи код којих се у инфинитиву разликује нагласак у односу на остале облике

\begin{tabular}{|l|l|l|l|l|}
\hline путовати & путовао & путујем & путују & путуј \\
\hline о оо & Ооо & Ооо & Ооо & ○о \\
\hline
\end{tabular}


Код глагола би се настава акцената могла повезати са наставом морфологије, јер се неке од ових уочених правилности важе само за одређене врсте глагола.

На крају дајемо пример вежбања, објављено претходно у акценатском квизу у Свету речи, које није у вези са врстом речи.

Упишите следеће речи у табелу.

дводимензионално, разгледница, готовински, послужитељ, вегетаријанац, заобилазница, летачица, љубичасто, ентузијазам, летовалиште, неизговорено, експресионизам, заробљеници, готовина, алтернатива, заглупљујући, намргођено, задржавање, ограничавати, еволуциони, заљубљивање, демобилисати, ватрогасац, преусмеравати, колонизовати, олакшица, задужење, посматрајући, интелектуални, модернизовати, економија, пројектовати, водоинсталатер, легализовање, амбициозно, импровизација

Сваки кружић означава слог, а пуни кружсић акиентовани (наглашени).

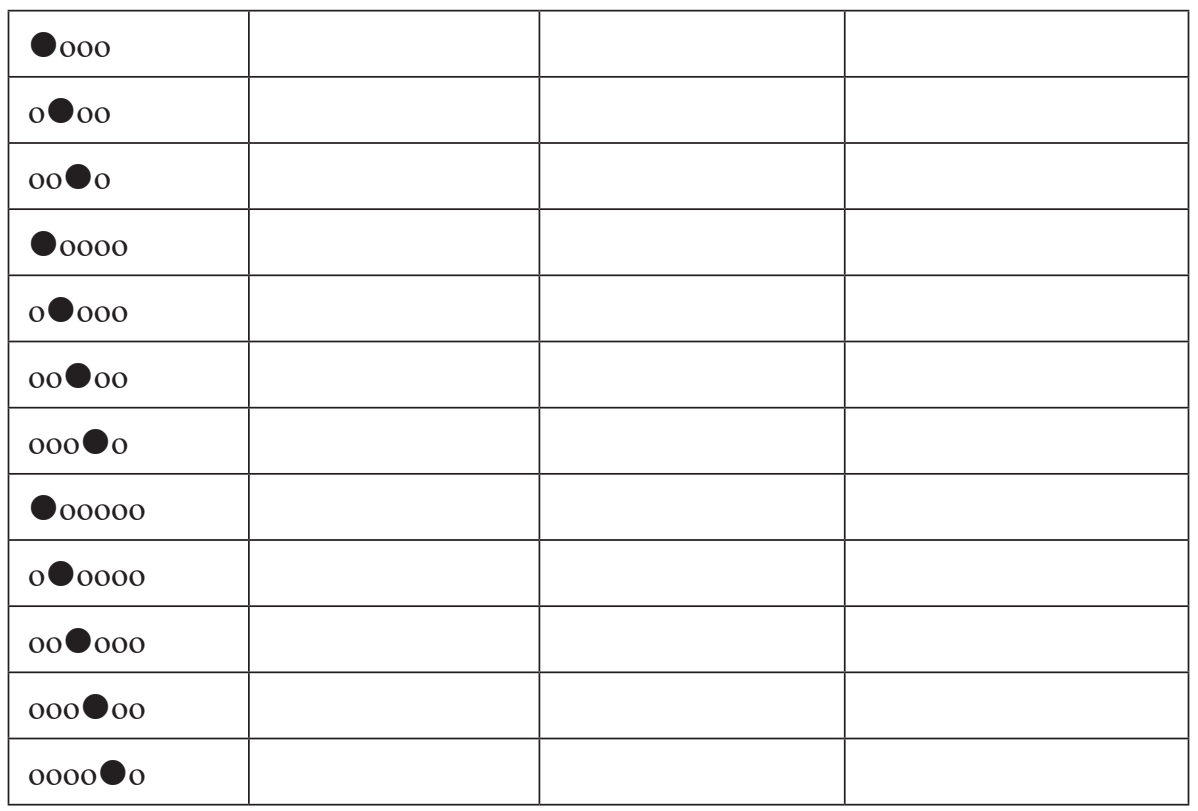

\section{ЛИТЕРАТУРА}

Батас 2020: Акценатске парадигме и алтернације у настави српског језика као страног", [in:] В. Крајишник (ур.) Српски као страни у теорији u пракси IV, Београд: Филолошки факултет, 2020, 89-102.

Гард 1993: Paul Garde, Naglasak, Zagreb: Školska knjiga. 
Дешић 1976: Милорад Дешић, „Акценатске парадигме у српскохрватском језику", Научни састанак слависта у Вукове дане, 5, 689-704.

Јокановић-Михајлов 2012: Јелица Јокановић-Михајлов, Прозодија и говорна култура, Београд: Друштво за српски језик и књижевност Србије.

Николић 1961-1962: Берислав Николић, Акценатске алтернације у савременом српскохрватском књижевном језику, Јужнословенски филолог, XXV, 185-196.

Пецо 1991: Asim Peco, Osnovi akcentologije srpskohrvatskog jezika, peto izdanje, Beograd: Naučna knjiga.

Шутова 2013: М. Н Шутова, Пособие по обучению русскому ударению для изучаюших русский язык как иностранный, Москва: Русский язык. Курсы.

Kъучч

\begin{tabular}{|c|c|c|c|}
\hline$\bullet$ о о о & разгледница & љубичасто & ол акшица \\
\hline $\mathrm{o} \bullet \mathrm{oo}$ & Готов ински & послужитељ & летачица \\
\hline $\mathrm{Oo} \bullet \mathrm{O}$ & готовина & ватрогасац & задужење \\
\hline$\bullet$ o o o o & летовалиште & пројектовати & амбицио зно \\
\hline $\mathrm{o} \bullet \mathrm{ooo}$ & заглупљују ћи & намргођено & посматрајући \\
\hline $\mathrm{Oo} \bullet \mathrm{oo}$ & задржавање & заљуб љивање & економија \\
\hline $0 \mathrm{oo} \bullet \mathrm{o}$ & ентузијазам & заробљенници & алтернатива \\
\hline$\bullet$ o o o o o & дводимензионално & еволуциони & интелектуални \\
\hline o• o o o o & колонизовати & легализовање & модернизовати \\
\hline oo• o o o & заобилазница & неизговорено & демобилисати \\
\hline $000 \bullet 00$ & ограничавати & преусмеравати & импров изација \\
\hline $0000^{\bullet} \mathrm{o}$ & вегетаријанац & експресионизам & водоинсталатер \\
\hline
\end{tabular}

